\title{
PERLINDUNGAN HUKUM TERHADAP KONSUMEN AIR MINUM ISI ULANG OLEH DINAS KESEHATAN DI KABUPATEN SLAWI
}

\author{
Aminudin Aziz ${ }^{*}$, Paramita Prananingtyas ${ }^{2}$, Irawati ${ }^{3}$ \\ 1Program Studi Magister Ilmu Hukum,Fakultas Hukum,Universitas Diponegoro \\ 2,3Fakultas Hukum,Universitas Diponegoro \\ Aminudin.azizsh@gmail.com
}

\begin{abstract}
Some of these refill drinking water products are not safe as drinking water because they do not meet standards, such as containing pathogenic germs. With the discovery of bacteria in refill drinking water that can cause health problems for consumers who consume it, the protection of consumers refills is considered important to protect the rights as consumers. This condition raises several problems such as the quality of drinking water refills and forms of legal protection against consumers. The method used in this study is empirical juridical. The quality of refill drinking water, especially in Slawi Subdistrict, Tegal Regency, can be said to be good, because most of the existing refill water depot business actors have registered their depots with the Health Service, by first passing on drinking water quality tests, bacteriological tests, and chemical test at the Health Office and get a healthy letter from the Health Office. And the implementation of legal protection for consumers of refill drinking water related to the implementation of quality standards in refill drinking water, is done by the presence of an MD number for registration of domestic food and beverage products and SNI related to the quality of a product.
\end{abstract}

\section{Keywords: Consumer Protection; Drinking Water Refill.}

\begin{abstract}
ABSTRAK
Sebagian produk air minum isi ulang tersebut tidak aman sebagai air minum karena tidak memenuhi standar, seperti mengandung kuman penyebab penyakit (patogen). Dengan ditemukannya bakteri dalam air minum isi ulang yang dapat menimbulkan gangguan kesehatan bagi konsumen yang mengkonsumsinya, maka perlindungan terhadap konsumen isi ulang dianggap penting guna melindungi hak-hak sebagai konsumen. Kondisi tersebut menimbulkan beberapa masalah seperti kualitas air minum isi ulang dan bentuk perlindungan hukum terhdap konsumen. Metode yang digunakan dalam penelitian ini adalah yuridis empiris. Kualitas air minum isi ulang khususnya di Kecamatan Slawi Kabupaten Tegal sudah bisa dikatakan baik, karena sebagian besar pelaku usaha depot air minum isi ulang yang ada sudah mendaftarkan depotnya ke Dinas Kesehatan, dengan terlebih dahulu lulus dalam hal uji kualitas air minum, uji bakteriologi, dan uji kimia pada Dinas Kesehatan dan mendapatkan surat layak sehat dari Dinas Kesehatan. Dan pelaksanaan perlindungan hukum terhadap konsumen air minum isi ulang berkaitan dengan penerapan standar mutu pada air minum isi ulang, di lakukan dengan adanya nomor MD nomor registrasi produk makanan dan minuman dalam negeri dan SNI yang berkaitan dengan kualitas suatu produk.
\end{abstract}

Kata Kunci : Air Minum Isi Ulang; Perlindungan Konsumen.

\footnotetext{
${ }^{*}$ Corresponding Author
} 


\section{A. PENDAHULUAN}

Masalah keamanan pangan di Indonesia disebabkan cemaran mikroba, cemaran kimiawi, penyalahgunaan bahan berbahaya dan penggunaaan bahan tambahan pangan berlebih (Zazili \& Hartono, 2018).

Di Indonesia kualitas air minum isi ulang mulai dipertanyakan setelah Badan POM melakukan pemeriksaan terhadap beberapa depot air minum isi ulang di 5 kota besar. Hasil pemeriksaan tersebut ditemukan kandungan bakteri Colliform pada air hasil produksi depot air minum isi ulang tersebut. Bakteri yang terdapat pada air minum isi ulang tidak menimbulkan reaksi pada waktu yang singkat. Namun dalam jangka waktu tertentu dapat menimbulkan sejumlah penyakit, seperti diare. Terdapatnya kandungan bakteri Colliform dalam air minum isi ulang disebabkan oleh faktor tidak sempurnanya higienitas produksi air minum isi ulang.

Sebagian produk air minum isi ulang tersebut tidak aman sebagai air minum karena tidak memenuhi standar, seperti mengandung kuman penyebab penyakit (patogen). Selain itu, untuk air minum isi ulang, tidak ada standardisasi, sehingga tidak bisa dikatakan mutu air minum isi ulang yang banyak diperjualbelikan saat ini adalah sama. Berbeda halnya dengan air minum dalam kemasan (AMDK), yang memiliki standar dan teregistrasi pada Badan Pengawas Obat dan Makanan (BPOM). Pengawasan kualitas air minum isi ulang yang dijual bebas di jalan menjadi tanggung jawab Dinas Kesehatan masing-masing daerah atau wilayah kota.
Hasil pemeriksaan sampel air minum isi ulang tahun 2005 dan tahun 2006 yang dilakukan suku Dinas Kesehatan Masyarakat menunjukan, antara 40 persen-60 persen dari sampel air yang diambil masih banyak mengandung bakteri E Coli. Misalnya di wilayah Kecamatan Slawi Kabupaten Tegal, di sini juga harus dilakukan pengawasan dan pembinaan, selain mengenai mutu air minum yang bersih juga mengenai proses perijinan dan tanggungjawab yang harus dilakukan oleh para pemilik depot air minum isi ulang yang ada di Kecamatan Slawi Kabupaten Tegal, supaya kualitas air minum tersebut tidak merugikan konsumen.

Istilah konsumen berasal dari alih bahsa dari kata consumer (inggris) atau consument (Belanda). Pengertian dari consumer/consument itu tergantung dalam posisi mana ia berada. Secara harfiah arti kata consumer adalah (lawan dari produsen) setiap orang yang mengenakan barang. Tujuan penggunanan barang dan/atau jasa menentukan termasuk kelompok mana pengguna tersebut. Begitu pula Kamus Besar Inggris-Indonesia memberi arti consumer sebagai pemakai atau konsumen. Konsumen dalam arti luas mencakup konsumen akhir dan konsumen bukan akhir, sedangkan konsumen dalam arti sempit hanya mengacu pada konsumen terakhir saja. Definisi tersebut dapat dipararelkan dengan definisi konsumen, yaitu: setiap orang pemakai barang dan/atau jasa yang tersedia dalam masyarakat, baik bagi kepentingan diri sendiri, keluarga, orang lain maupun makhluk hidup lain dan tidak untuk diperdagangkan (Nasution, 2001). 
Sesuai dengan amanat alinea ke-IV ataupun melanggar ketentuan undang-undang. Pembukaan Undang-Undang Dasar Negara Republik Dalam keadaan ini termasuk pula persoalan Indonesia Tahun 1945, maka perlindungan mengenai penggunaan bahan baku, proses produksi, konsumen menjadi penting (Setiantoro, Putri, distribusi, desain produk dan sebagainya. Apakah Novitarani, \& Njatrijani, 2018).

Istilah 'perlindungan konsumen' seringkali dipakai untuk menggambarkan perlindungan dalam bidang hukum yang diberikan kepada konsumen dalam upaya untuk menjamin terpenuhinya kebutuhan dimaksud terhadap hal-hal yang dapat merugikan konsumen tersebut (Shidarta, 2006). Pasal 1 angka 1 Undang-Undang Nomor 8 Tahun 1999 tentang Perlindungan Konsumen disebutkan bahwa Perlindungan Konsumen adalah segala upaya yang menjamin adanya kepastian hukum untuk memberi perlindungan kepada konsumen (Prananingtyas, 2018).

Di dalam penyusunan batasan dari hukum perlindungan konsumen selama ini tampaknya dipersulit oleh belum adanya pengalaman khusus berkaitan dengan perlindungan konsumen (Shidarta, 2006). Perlindungan konsumen itu sendiri memiliki cakupan yang luas, dimana selain meliputi perlindungan terhadap konsumen barang dan jasa, terdapat pula perlindungan sebagai akibat dari timbulnya pemakaian barang dan/atau jasa dikemudian hari. Adapun cakupan perlindungan konsumen dalam 2 (dua) aspeknya tersebut dapat dijelaskan sebagai berikut. Cakupan pertama perlindungan terhadap kemungkinan diserahkan kepada konsumen barang dan/atau jasa yang tidak telah sesuai dengan standar sehubungan dengan keadaan dan keselamatan konsumen atau tidak. Dalam hal ini, termasuk pula tentang bagaimana konsumen mendapatkan penggantian atas kerugian yang timbul akibat atau menggunakan produk yang tidak sesuai tersebut. Cakupan kedua perlindungan diberlakukan kepada konsumen adalah perlindungan terhadap syarat-syarat yang tidak adil dan memberatkan satu pihak saja. Dalam kaitan ini termasuk persoalan- persoalan promosi dan periklanan. Standar kontrak, harga, layanan purnajual dan sebagainya. Hal ini berkaitan dengan perilaku produsen didalam memproduksi dan mengedarkan produknya kepada konsumen (Shidarta, 2006). Dalam kegiatan bisnis yang sehat terdapat keseimbangan perlindungan hukum antara konsumen dengan produsen (Nangin, 2017).

Perlindungan konsumen merupakan hal yang masih relatif baru di Indonesia, tetapi masih banyak kasus konsumen yang dirugikan tetapi konsumen merasa kesulitan untuk menuntut ganti rugi, bahkan konsumen terkesan sangat lemah kedudukannya di hadapan pelaku usaha, karena yang menjadi kebiasaan di Indonesia adalah asas "take it or leave it", konsumen di Indonesia hanya dijadikan objek aktivitas bisnis oleh para pelaku usaha (Suyadi, 2010). 
Apabila diperhatikan kondisi konsumen di Indonesia dewasa ini, maka tampak bahwa posisi konsumen masih sangat lemah dibanding produsen, sehingga perlu adanya pemberdayaan konsumen agar posisi tidak selalu pada pihak yang dirugikan. Pemberdayaan konsumen dapat dilakukan melalui penerapan hukum perlindungan konsumen yang memadai, dimana perlindungan konsumen ini menjadi relevan pada tiga tahap transaksi konsumen, yaitu prapembelian, saat pembelian, dan purna pembelian (Miru, 2013).

Terdapat beberapa Penelitian sebelumnya yang membahas mengenai perlindungan konsumen dengan tema yang hampir sama yaitu terhadap penggunaan air ,juga terkait dengan perlindungan konsumen. Penelitian tersebut menyatakan bahwa Proses pendirian usaha air minum haruslah memenuhi prosedur yang telah ditentukan oleh Pemerintah diantaranya mengurus Surat Izin Tempat Usaha kekantor Walikota, menguji Sampel air untuk mendapatkan Rekomendasi Laik Sehat dar Dinas Kesehatan Kota, Mendaftarkan Disperindagtamben berupa Tanda Datar Perusahaan dan memperoleh Surat Izin Usaha Perdagangan,hal ini dikemukakan oleh Rahdiansyah (Rahdiansyah, 2018). Juga terkait dengan bentuk perlindungan sebagai pengawasan terhadap usaha air minum isi ulang dalam memberikan perlindungan hukum.

Penelitian yang selanjutnya adalah milik Nurdiyana Tadjuddin yang menyatakan bahwa dalam memberikan pelayanan air bersih Perusahaan Air (PDAM) memiliki peran demi dihasilkannya air minum yang sehat. Dalam memberikan pelayanan air bersih,PDAM di daerah Una - Una Kabupaten Tojo Sulawesi Tengah juga harus memenuhi hak - hak konsumen sesuai dengan Undang - Undang Perlindungan Konsumen serta harus memperbaiki kinerjanya serta meningkatkan pelayanan kepada masyarakat agar lebih maksimal (Tadjuddin, 2017).

Adapun terdapat penelitian internasional yang juga membahas mengenai kebutuhan air bersih untuk kehidupan sehari hari termasuk dikonsumsi di suatu negara .Bahwa pentingnya air sebagai kebutuhan utama seringkali masyarakat tidak memperhatikan kebersihan dan kandungan air yang dikonsumsi. Sehingga diperlukan kesadaran dari masyarakat setempat juga peran negara melalui pemerintah untuk melakukan pengawasan dan memastikan ketersediaan air bersih bagi warga negara. air yang tidak bersih dapat berdampak buruk pada lingkungan,sosial maupun perekonomian (Constantine, Massoud, Alameddine, El-Fadel, 2017).

Pada penelitian selanjutnya yang membahas air minum kemasan di Malaysia menyatakan bahwa memperhatikan kualitas hidup pada konsumen dilakukan salah satunya dengan menjaga kualitas air yang dikonsumsi, sehingga peraturan perundang undangan sebagai regulasi mampu memberikan perlindungan bagi konsumen dan kelestarian lingkungan pada air minum kemasan (Razman, Suhor, Yussof, Azlan, 2012).

Juga terdapat penelitian dengan pembahasan mengenai pembinaan dan pengawasan pada depot 
air minum isi ulang dikatakan bahwa bahwa pembinaan dan pengawasan oleh Dinas Kesehatan memiliki pengaruh secara signifikan terhadap air minum isi ulang yang dproduksi. Hasil juga menunjukkan bahwa pembinaan merupakan faktor yang paling dominan, dimana pembinaan memiliki pengaruh terhadap kualitas depot air minum isi ulang sebanyak 39 kali lipat di bandingkan pembinaan yang kurang baik (Iqbal, Darmana, Syamsul, 2019).

Konsumen dan pelaku usaha adalah ibarat sekeping mata uang dengan dua sisi yang berbeda. Konsumen membutuhkan produk (barang/jasa) yang hasil kegiatan pengusaha, tetapi kegiatan pengusaha itu akan mubazir apabila tidak ada konsumen yang menyerap/atau membeli hasil usahanya. Karena itu keseimbangan dari segala segi, menyangkut kepentingan dari kedua belah pihak ini merupakan hal yang ideal dan harus diperhitungkan (Nasution, 2001).

Permasalahan yang dihadapi konsumen saat ini tidak hanya sekedar bagaimana memilih barang atau jasa yang dikonsumsinya, tetapi lebih kompleks dari itu yang menyangkut pada kesadaran semua pihak (Sari, Hamzah \& Rusmawati, 2018).

Maka perlindungan konsumen dilakukan terhadap transaksi antara pelaku usaha dengan konsumen yang obyek sengketanya dapat berupa barang bergerak, barang tak bergerak, dan barang tak bertubuh (Rachmanto, 2018).

Oleh karena itu, dibutuhkan suatu landasan hukum untuk melindungi konsumen sehingga hakhaknya dapat dilindungi dan tidak diabaikan oleh pelaku usaha. Undang-Undang Nomor 8 Tahun 1999 tentang Perlindungan Konsumen (UUPK) merupakan landasan hukum bagi penyelenggaraan perlindungan konsumen di Indonesia. Landasan tersebut didukung pula oleh Teori perlindungan konsumen Menurut Satjipto Rahardjo, perlindungan hukum adalah memberikan pengayoman terhadap hak asasi manusia (HAM) yang dirugikan orang lain dan perlindungan itu diberikan kepada masyarakat agar dapat menikmati semua hak-hak yang diberikan oleh hukum.

Masalah perlindungan konsumen menjadi sangat menarik dan mendasar untuk dibahas, karena banyak dijumpai pelanggaran/atau penyimpangan dalam hubungan antara konsumen dengan pelaku usaha dan kadang merugikan pihak konsumen tanpa adanya kepastian hukum tentang apa yang menjadi hak-hak konsumen. Untuk itu menarik untuk dikaji, Apakah Kualitas air minum isi ulang di kab. Slawi telah memenuhi persyaratan sebagaimana diatur dalam KEPMEN No.907/MENKES/SKNII/2002 Tentang syarat-syarat dan pengawasan kualitas air minum dan bentuk perlindungan hukumnya.

\section{B. METODE PENELITIAN}

Jenis penelitian hukum yang digunakan dalam penelitian ini adalah jenis penelitian hukum sosiologis atau yuridis empiris. Sebagaimana yang dikemukakan oleh Soerjono Soekanto, penelitian jenis ini adalah penelitian yang memfokuskan terhadap identifikasi hukum dan efektifitas hukum (Sunggono, 2007). Jenis penelitian yuridis empiris ini 
pada dasarnya dapat menggabungkan antara data yang didapatkan dilapangan dengan data yang didapatkan melalui penelusuran literatur terkait dengan topik yang menjadi fokus penelitian (Waluyo, 2002). Dalam hal ini penulis menggali informasi terkait dengan perlindungan hukum terhadap konsumen air minum isi ulang dan mengkomparasikan hasil penelitian lapangan tersebut dengan hasil penelusuran kepustakaan berupa literatur atau buku-buku serta peraturan yang berlaku terkait dengan topik penelitian.

Data primer dalam penelitian ini diperoleh dari hasil observasi dan wawancara dengan pedagang depot air minum isi ulang palma dan dinas kesehatan kabupaten tegal. Data sekunder adalah jenis data yang mendukung dan menunjang kelengkapan data primer melalui bahan literature seperti buku-buku, jurnal, teoriteori, ataupun peraturan-peraturan yang terkait dengan topik penelitian ini. Dalam konteks penelitian ini peraturan yang dimaksud antara lain Undang-Undang Nomor 8 Tahun 1999 tentang Dana Pensiun, KEPMENKES RI No.907/MENKES/SK/VII/2002 Tentang syarat-syarat dan pengawasan kualitas air minum dan KEPMEN PERINDAG RI No. 651/MPP/KEP/10/2004 Tentang persyaratan teknis depot air minum dan perdagangan. Teknik pengumpulan data yang digunakan untuk memperoleh data primer ialah melalui observasi dan wawancara (Interview) secara langsung dengan pimpinan dan/atau staf dinas kesehatan kabupaten tegal dan pedagang depot air minum isi ulang palma sehingga didapatkan data yang dibutuhkan. Data yang diperoleh baik dari penelitian kepustakaan maupun dari penelitian lapangan diolah berdasarkan analisis deskriptif kualitatif. Pengertian deskriptif adalah memberikan data secara jelas tentang keadaan atau gejala-gejala lainnya dan kualitatif ialah analisis terhadap data yang dinyatakan oleh responden dan narasumber yang kemudian diuraikan sehingga diperoleh suatu pengertian.

\section{PEMBAHASAN}

1. Kualitas Air Minum Isi Ulang Berdasarkan Kepeutusan Menteri Kesehatan No. 907/ME NKES/SK/NII/2002

a) Persyaratan pendirian depot air minum isi ulang khususnya di Kecamatan Slawi, Kabupaten Tegal.

Keputusan Menteri Perindustrian dan Perdagangan RI dalam Pasal 2 No. 651/MPP/Kep/10/2004 Tentang Persyaratan Teknis Depot Air Minum dan Perdagangannya menentukan, bahwa untuk mendidirkan usaha depot air minum isi ulang, pelaku usaha harus memenuhi syarat-syarat yaitu Depot Air Minum wajib memiliki Tanda Daftar Industri (TDI) dan Tanda Daftar Usaha Perdagangan (TDUP) dengan nilai investasi perusahaan seluruhnya sampai dengan Rp. 200.000.000,00 (dua ratus juta rupiah), memiliki surat Jaminan Pasok Air Baku dari PDAM atau perusahaan yang memiliki izin pengambilan air dari Instansi yang berwenang, memiliki laporan hasil uji air minum yang dihasilkan dari laboratorium pemeriksaan kualitas air yang 
ditunjuk Pemerintah Kabupaten/Kota atau yang terakreditasi.

Dengan dipenuhinya proses perijinan tersebut oleh pengusaha depot air minum isi ulang, maka sudah sesuai dengan Pasal 7 Undang-undang No. 8 Tahun 1999 Tentang Perlindungan Konsumen, dimana pelaku usaha harus beritikad baik dalam menjalankan usahanya, memberikan informasi dengan benar, jelas, serta jujur mengenai kondisi dan jaminan barang dan/atau jasa, serta memberi penjelasan penggunaan, perbaikan dan pemeliharaan serta menjamin mutu barang dan/atau jasa yang diproduksi dan/atau diperdagangkan berdasarkan ketentuan standar mutu barang dan/atau jasa yang berlaku, supaya tidak merugikan konsumen khususnya bagi konsumen pengguna air minum isi ulang.

\section{b) Pendaftaran Depot Air Minum Isi Ulang di Dinas Kesehatan Kabupaten Tegal}

Berkaitan dengan kualitas air minum isi ulang biasanya ditentukan bahwa suatu Depot Air Minum Isi Ulang dikatakan berkualitas apabila pelaku usaha depot air minum tersebut sudah mendaftarkan di Dinas Kesehatan Kabupaten/Kota yang setelah melalui proses pendaftaran akan mendapatkan surat keterangan ljin layak Sehat dari Dinas Kesehatan Kabupaten Tegal, namun demikian prosesnya harus malalui uji teknis dari lembaga terkait yaitu Dinas Kesehatan setempat dan khususnya Kecamatan Slawi Kabupaten Tegal dan untuk proses pendaftaranya yaitu (Nuraeny, 2018) Pelaku usaha mengisi formulir permohonan untuk memperoleh surat keterangan ijin layak sehat pada Dinas Kesehatan Kabupaten Tegal dengan mengisi serta melampirkan syarat yaitu; nama pelaku usaha depot air minum, No KTP, Nama usaha dan produk usaha, surat keteangan puskesmas setempat, denah lokasi usaha, dan hasil pemeriksaan sampel air minum isi ulang.Kemudian pelaku usaha juga wajib melakukan retribusi (pembayaran) sebesar Rp 50.000,00.

Setelah semua persyarataan pendaftaraan dilaksanakan oleh pelaku usaha, pelaku usaha depot membuat kesepakatan dengan pegawai dinas kesehatan yang berwenang dalam hal ini, membuat kesepakatan untuk tinjauan lapangan (guna untuk kegiatan inspektasi, pengambilan sampel). Sesuai dengan Keputusan Menteri Kesehatan 907/MenKes/SK/VII/2002 tentang syarat-syarat dan pengawasan kualitas air minum, Dinas Kesehatan Kabupaten Tegal. Menerangkan bahwa air yang dikonsumsi oleh masyarakat harus diperiksa terlebih dahulu dengan melakukan sampel air minum untuk diperiksa di tempat atau di lapangan dan/atau dapat di laboratorium, bahwa air minum harus memenuhi persyaratan tingkat kontaminasi nol untuk keberadaan bakteri coliform dan bisa dikatakan bahwa air minum tersebut layak dan sehat untuk dikonsumsi.

\section{c) Persyaratan Kualitas Air Minum yang Sehat dan Pengawasan yang Dilakukan Oleh Dinas Kesehatan}


Penelitian menunjukan beberapa pelaku usaha depot air minum isi ulang yang tidak merawat alatnya secara baik, tidak mengganti mikrofilternya akibatnya setelah dilakukan uji sampel hasilnya kualitas air tersebut tidak baik. Berbeda dengan pelaku usaha air minum yang secara rutin mengganti mikrofilternya sehingga apabila dilakukan uji sampel kualitas air minum hasilnya pun baik. Oleh karena itu semua terjadi apabila pelaku usaha air minum secara rutin memelihara dengan baik alat-alat tersebut sehingga kualitas air minum tersebut tidak berubah yang seharusnya baik menjadi tidak baik, di sini faktor pemeliharaan penting bagi para pelaku usaha air minum isi ulang supaya tidak mempengaruhi kualitas air minum tersebut (Behaki, 2018).

Air baku yang digunakan oleh pelaku usaha juga mempengaruhi baik atau buruknya kualitas air minum isi ulang apabila dilakukan uji sampel oleh dinas kesehatan, oleh karena itu perawatan terhadap alat harus dilakukan secara rutin oleh pelaku usaha diantaranya perawatan secara berkala terhadap mesin proses supaya kualitas air tetap terjaga dengan baik

Dalam pasal 2 ayat 2 Keputusan Menteri Kesehatan No.907/MENKES/SK/VII/2002 Tentang syarat-syarat dan pengawasan kualitas air minum, dijelaskan bahwa air minum harus memenuhi syarat fisik, kimia, dan mikrobiologi yaitu : air tidak boleh berasa, berwarna ataupun berbau, syarat kimia mengharuskan air bebas dari kandungan bahan kimia berbahaya melalui tes laboratorium dapat diteliti dari segi kimia. Air minum harus bebas dari kandungan zat kimia berbahaya, seperti logam berat air raksa atau merkuri $(\mathrm{Hg})$, timbal $(\mathrm{Pb})$ dan $(\mathrm{Au})$ aluminium, besi, serta klorida, dan syarat mikrobiologi, tidak boleh mengandung bakteri-bakteri patogen (bersifat racun sehingga dapat menimbulkan penyakit). Bakteri yang tergolong patogen adalah E.coli, Salmonella typhii, dan sejenisnya.

Dengan dijelaskannya tentang syarat air minum yang sehat pada Pasal 2 ayat 2 Keputusan Menteri Kesehatan tersebut, maka air minum isi ulang di Kecamatan Slawi Kabupaten Tegal seharusnya sebagian besar yang dijual oleh para pelaku usaha sudah layak untuk di konsumsi sehingga tidak merugikan konsumen karena telah memenuhi syarat air minum yang ditetapkan oleh Menteri Kesehatan serta layak dikonsumsi bila mendapatkan ijin dan mendapatkan surat layak sehat dari Dinas Kesehatan.

\section{Perlindungan Hukum Terhadap Konsumen Air Minum Isi Ulang}

Konsumen dan pelaku usaha mempunyai hubungan yang sejajar, karena saling membutuhkan (Herlina \& Santi, 2018). Hubungan yang saling membutuhkan antara pelaku usaha dengan konsumen dalam kegiatan bisnis sering terjadi. Hubungan itu terkait dengan penggunaan dan pemanfaatan barang maupun jasa yang dijual oleh pelaku usaha (Riza \& Abduh, 2018).

Perlindungan konsumen mempunyai cakupan yang luas meliputi perlindungan konsumen dalam memperoleh barang dan jasa, yang berawal dari 
tahap kegiatan untuk mendapatkan barang dan jasa hingga ke akibat-akibat dari pemakaian barang dan jasa itu (Sidabalok, 2014).

Pasal 1 angka 1 Undang-Undang No. 8 Tahun 1999 Tentang Perlindungan Kosumen menyatakan bahwa, Perlindungan konsumen adalah segala upaya yang menjamin adanya kepastian hukum untuk memberi perlindungan kepada konsumen.

Hasil penelitian khususnya di Kecamatan Slawi Kabupaten Tegal, lembaga terkait yang saat ini berperan dalam melakukan pengawasan dan perlindungan terhadap konsumen isi ulang adalah Dinas Kesehatan Kabupaten Tegal, Dinas Kesehatan setempat melakukan kegiatan sosialisasi kepada masyarakat sebagai konsumen air minum isi ulang, kegiatan sosialisasi ini harus dilakukan supaya konsumen diharapkan lebih teliti dalam memilih air minum untuk dikonsumsi supaya tidak membahayakan bagi kesehatan konsumen apabila dikonsumsi secara terus-menerus.

Dalam undang-undang perlindungan konsumen menyatakan bahwa pemerintah bertanggung jawab atas pembinaan dan penyelenggaraan perlindungan konsumen yang menjamin di perolehnya hak konsumen dan pelaku usaha. Di dalam Undang -undang perlindungan konsumen juga telah mengakui adanya hak-hak dari konsumen untuk membentuk suatu wadah/organisasi yang dianggap dapat membantu maupun melindungi hak-hak kepentingan konsumen. Organisasi ini adalah Badan Perlindungan Konsumen Nasional yang berfungsi memberikan saran dan pertimbangan kepada pemerintah dalam upaya mengembangkan perlindungan konsumen di Indonesia Oleh karena itu konsumen sebagai pemakai barang dan/atau jasa yang tersedia dalam masyarakat memiliki hak-hak yang dilindungi oleh undang-undang. Dalam Undangundang No. 8 Tahun 1999 telah dijelaskan secara lengkap mengenai aspek-aspek regulasi yang berlaku dalam setiap konsumen di Indonesia mempunyai hak-hak yang diatur dalam Pasal 4 Undang-undang No.8 tahun 1999 tentang Perlindungan Konsumen, yaitu :

Hak atas kenyamanan, keamanan, dan keselamatan dalam mengkonsumsi barang dan/jasa, Hak untuk memilih barang-barang dan/atau jasa serta mendapatkan barang dan/atau jasa tersebut sesuai dengan nilai tukar dan kondisi serta jaminan yang dijanjikan, Hak atas informasi yang benar, jelas, dan jujur mengenai kondisi dan jaminan barang dan/atau jasa, Hak untuk didengar pendapat dan keluhanya atas barang dan/atau jasa yang digunakan, Hak untuk mendapatkan advokasi, perlindungan dan upaya penyelesaian sengketa perlindungan konsumen secara patut, Hak untuk mendapat pembinaan dan pendidikan konsumen, Hak untuk diperlakukan atau dilayani secara benar dan jujur serta tidak diskriminatif, dan Hak mendapatkan dispensi, ganti rugi dan/atau penggantian jika barang dan/atau jasa yang diterima tidak sesuai dengan perjanjian atau tidak sebagaimana mestinya.

Penerapan standar mutu pada air minum isi ulang dibuktikan berdasarkan surat yang dikeluarkan 
oleh Dinas Kesehatan Kabupaten Tegal baik berupa pendaftaran depot air minum isi ulang di Dinas Kesehatan yang nantinya akan mendapatkan surat layak sehat dari Dinas Kesehatan maupun surat hasil pemeriksaan kimia dan bakteriologi air minum yang harus dipenuhi oleh pelaku usaha depot air minum sesuai Keputusan Menteri Kesehatan 907/MENKES/SK/VII/2002 tentang Syarat-syarat dan Pengawasan Kualitas Air Minum. Dan disertai dengan upaya yang dilakukan oleh pelaku usaha depot air minum dalam menjaga kualitas air minum isi ulang yaitu mengambil sumber air langsung dari air mata pengunungan, menjaga kebersihan tempat, bak penampungan air baku, dan galon, mengurus izin layak sehat air minum isi ulang dari Dinas Kesehatan Kabupaten Tegal, memeriksa sample air secara rutin ke laboratorium, memperbaiki dan menjaga kualitas air sesuai petunjuk yang diberikan oleh Dinas Kesehatan berdasarkan hasil pemeriksaan yang telah dilakukan, memberikan pelayaan yang baik kepada konsumen.

Selain itu bagi usaha yang bergerak dalam bidang air minum isi ulang, berdasarkan Kep. Menperindag No. 705/MPP/Kep/I/2003, harus memiliki nomor MD dan SNI untuk memperoleh izin usaha. SNI adalah Standar Nasional Indonesia (SNI) 01 35543-1996, yang berkaitan dengan kualitas suatu produk. SNI ditetapkan oleh Badan Pengawas Obat dan Makanan, setelah melalui serangkaian tes laboratorium. Sedangkan nomor MD adalah nomor registrasi produk makanan dan minuman dalam negeri. Apabila standar mutu kualitas air minum isi ulang tersebut tidak terpenuhi oleh pelaku usaha depot air minum isi ulang dapat merugikan konsumen itu sendiri.

Dengan demikian dapat dipahami bahwa konsumen pengguna air minum isi ulang khususnya di Kecamatan Slawi Kabupaten Tegal sebagian besar bisa menerima air minum isi ulang tersebut dengan kondisi yang diharapkan supaya tidak merugikan setiap konsumen. Tetapi mengenai perlindungan hukum terhadap konsumen air minum isi ulang di Kecamatan Slawi Kabupaten Tegal harus ditingkatkan lagi dengan upaya sosialisasi dan keterbukaan informasi oleh pelaku usaha, walaupun belum sesuai dengan apa yang dijelaskan menurut AZ Nasution, beliau menjelaskan bahwa hukum perlindungan konsumen merupakan bagian dari hukum konsumen yang memuat asas-asas atau kaidah-kaidah yang bersifat mengatur dan juga mengandung sifat melindungi kepentingan setiap konsumen. Asas keamanan dan keselamatan perlindungan konsumen air minum isi ulang di kabupaten slawi harus di implementasikan sebagai bentuk pelaksanaan Undang-Undang No.8 Tahun 1999 Tentang Perlindungan Konsumen.

Peran pelaku usaha depot air minum dalam mengawasi kualitas air minum isi ulang khususnya yang berada di Kecamatan Slawi Kabupaten Tegal yang sudah cukup baik, tetapi harus ditingkatkan peran aktif pelaku usaha depot air minum isi ulang dalam menjaga kualitas air minum isi ulang tersebut, khususnya dalam menjaga dan memelihara peralatan usahanya dengan baik dan benar. Supaya 
tidak mempengaruhi kualitas air minum isi ulang tersebut, sehingga tidak merugikan kedua belah pihak antara pelaku usaha dengan konsumen khususnya konsumen pengguna air minum isi ulang.

Sanksi administratif dan pidana bagi pelaku usaha yang melanggar ketentuan Undang-Undang No.8 Tahun 1999 Tentang Perlindungan Konsumen.

\section{SIMPULAN}

Perlindungan hukum terhadap konsumen air minum isi ulang khususnya di Kecamatan Slawi Kabupaten Tegal harus ditingkatkan lagi, walaupun peran pelaku usaha depot air minum dalam mengawasi kualitas air minum isi ulang khususnya yang berada di Kecamatan Slawi Kabupaten Tegal yang sudah cukup baik, tetapi harus ditingkatkan peran aktif pelaku usaha depot air minum isi ulang dalam menjaga kualitas air minum isi ulang tersebut, dan memberikan pengawasan pada produk air minum isi ulang yang diproduksi pada konsumen. Selain itu apabila ada salah satu konsumen pengguna air minum isi ulang yang dirugikan, apabila terjadi kelalaian pelaku usaha dalam menjaga air minum isi ulang tersebut dan tidak memenuhi standar mutu yang baik yang telah ditetapkan Dinas Kesehatan pada air minum isi ulang dapat merugikan konsumen itu sendiri.

Penerapan standar mutu pada air minum isi ulang dibuktikan berdasarkan surat layak sehat yang dikeluarkan oleh Dinas Kesehatan Kabupaten Tegal baik berupa pendaftaran depot air minum isi ulang di Dinas Kesehatan yang nantinya akan mendapatkan surat layak sehat dari Dinas Kesehatan maupun hasil pemeriksaan bakteriologi dan kimia pada air minum yang harus dipenuhi oleh pelaku usaha depot sesuai Keputusan Menteri Kesehatan, serta disertai dengan upaya yang dilakukan oleh pelaku usaha depot air minum dalam menjaga kualitas air minum isi ulang yaitu, menjaga kebersihan tempat air baku, mengurus izin nomor MD dan SNI, mengurus izin surat layak sehat air minum isi ulang di Dinas Kesehatan Kabupaten Tegal, memeriksa sample air secara rutin ke laboratorium, memperbaiki dan menjaga kualitas air sesuai petunjuk yang diberikan oleh Dinas Kesehatan berdasarkan hasil pemeriksaan yang telah dilakukan, memberikan pelayaan yang baik kepada konsumen.

Apabila standar mutu kualitas air minum isi ulang tersebut tidak terpenuhi oleh pelaku usaha depot air minum isi ulang dapat merugikan konsumen itu sendiri. Rata-rata konsumen tidak berani komplain mengenai masalah penggunaan air minum isi ulang apabila air minum isi ulang tersebut merugikan mereka, tapi secara keseluruhan konsumen air minum isi ulang bisa menerima air minum isi ulang tersebut dengan kondisi seperti yang diharapkan.

\section{DAFTAR PUSTAKA}

\section{BUKU}

Miru, A. (2013). Prinsip-Prinsip Perlindungan Hukum Bagi Konsumen di Indonesia. Jakarta: Raja Grafindo Perdasa

Nasution, AZ. (2001). Hukum Perlindungan Konsumen. Jakarta: Diadit Media 
Jurnal Pembangunan Hukum Indonesia

Volume 1, Nomor 2, Tahun 2019
Program Studi Magister Ilmu Hukum Fakultas Hukum Universitas Diponegoro
Sunggono, B. (2007). Metodologi Penelitian Hukum.,

Cet 1. Jakarta: Raja Grafindo Persada.

Sidabalok, J. (2014). Hukum Perlindungan

Konsumen di Indonesia. Bandung: Citra Aditya

Bakti.

Waluyo, B. (2002). Penelitian Hukum Dalam Praktek. Jakarta: Sinar Grafika.

Shidarta. (2006). Hukum Perlindungan Konsumen Indonesia. Jakarta: Grasindo

\section{JURNAL}

Constantine, Kinda., Massoud, May., Alameddine, Ibrahim., \& El-Fadel, Mutasem.(2017). The role of the water tankers market in water stressed semi-arid urban areas:Implications on water quality and economic burden. J ournal of Environmental Management, 188, pp.85-94.

Iqbal, Muhammad., Darmana, Ayu., \& Syamsul, Darwin. (2019). Pembinaan Dan Pengawasan Dinas Kesehatan Terhadap Kualitas Depot Air Minum Isi Ulang Di Kabupaten Simeulue Tahun 2018. Contagion: Scientific Periodical

Of Public Health And Coastal Health, Vol.1,(No1), pp.1-10.

Herlina, Elis., \& Santi, Sri. (2018). Perlindungan Hukum Terhadap Konsumen Pada Perjanjian Pembiayaan Dengan Fidusia Tidak Terdaftar. Jurnal Hukum lus Quia Iustum, Vol. 25, (No.2), p.290.

Razman, Muhammad Rizal., Suhor, Shamsuddin., Yussof, Syakina Syaid Ahmad., \& Azlan, Azrina. (2012). Consumer Protection and
Environmental Sustainability on Drinking Bottled Water from Malaysian Sale of Goods Law Perspectives: Focusing on Statutory Implied Terms. Research J ournal of Applied Sciences, Vol.7, (No.1), pp.36-40.

Nangin, C. (2017). Perlindungan Hukum Terhadap Konsumen Yang Mengalami Kerugian Akibat Pengiriman Barang Oleh Perusahaan Ekpedisi Menurut UU Nomor 8 Tahun 1999 Tentang Perlindungan Konsumen, Lex Crimen, Vol. VI (No.4), pp.62-70.

Tadjuddin, N. (2017). Perlindungan Hukum Bagi Konsumen Air Bersih Atas Layanan Perusahaan Daerah Air Minum "Ue Tanah" Kabupaten Tojo Una-Una Ditinjau Dari Undang-Undang No. 8 Tahun 1999 Tentang Perlindungan Konsumen. J urisprudentie, Vol 4, No.1), pp.103-22.

Prananingtyas, P. (2018). Perlindungan Hukum Terhadap Investor Emas. Jurnal MasalahMasalah Hukum, Jilid 47 (No.4,Oktober), pp. 444-445.

Rachmanto, A Dwi. (2018). Penyelesaian Sengketa Konsumen Akibat Perjanjian Baku Dan Klausula Baku Pasca Keberlakuan UndangUndang No. 21 Tahun 2011 Tentang Otoritas Jasa Keuangan. J urnal Hukum \& Pembangunan, Vol.48, (No.4), p.840

Rahdiansyah. (2018). Perlindungan Hukum Terhadap Konsumen Pelanggan Air Minum Isi Ulang. UIR Law Review, Vol.2, (No.2), pp.347353. 
Jurnal Pembangunan Hukum Indonesia

Volume 1, Nomor 2, Tahun 2019
Program Studi Magister Ilmu Hukum Fakultas Hukum Universitas Diponegoro

Riza, Faisal., \& Abduh, Rachmad. (2018). Keputusan Menteri Kesehatan No. Penyelasaian Sengketa Secara Arbitrase Untuk Melindungi Konsumen Melalui Badan Penyelesaian Sengketa Konsumen. Jurnal EduTech, Vol 4 (No.1), p.30

Sari, Aini Puspita., Hamzah., \& Rusmawati, Dianne Eka. (2018). Perlindungan Hukum Bagi Konsumen Muslim Terhadap Penjualan Makanan Menggunakan Campuran Daging Babi. Pactum Law Jurnal, Vol 1, (No.3), p.183.

Setiantoro, Arfian., Putri, Destika Fayreizha., 907/MENKES/SK/VII/2002 Tentang SyaratSyarat dan Pengawasan Kualitas Air Minum Keputusan Menteri Perindustrian dan Perdagangan RI dalam Pasal 2 No. 651/MPP/Kep/10/2004 Tentang Persyaratan Teknis Depot Air Minum

\section{WAWANCARA}

Behaki, A. Wawancara Pedagang Depot Air Minum Isii Ulang Palma, Kab.Tegal, 26 Juli 2018

Nuraeny, S. Wawancara Seksi Penyuluhan Dinas Kesehatan Kab.Tegal, 25 Juli 2018

Novitarani, Anisah., \& Njatrijani, Rinitami. (2018). Urgensi Perlindungan Hukum Konsumen Dan Penyelesaian Sengketa ECommerce Di Era Masyarakat Ekonomi ASEAN. J urnal Rechtsvinding, Vol 7, (No.1), p.2

Suyadi. (2010). Perlindungan Hukum Terhadap Konsumen Produk Pangan Olahan Yang Mengandung Bahan Rekayasa Genetika. J urnal Dinamika Hukum, Vol 10 (No.1),p.70

Zazili, Ahmad., \& Hartono. (2018). Model Pemberdayaan Konsumen Terhadap Ancaman Bahaya Produk Pangan Tercemar Bahan Berbahaya Beracun di Provinsi Lampung. Jurnal lus Quia lustum, Vol 23 (No.3),p. 392.

\section{PERATURAN PERUNDANG-UNDANGAN}

Undang-Undang Nomor 8 Tahun 1999 tentang Perlindungan Konsumen 